\title{
東北地方太平洋沖地震津波による田老漁港の漁港施設における 被災メカニズムの検討
}

\section{A Study of Damage Mechanism on Fishery Port Facilities at Taro Fishery Port due to TOHOKU Earthquake Tsunami}

\author{
八木 宏 $^{1} \cdot{\text { 杉松宏 }{ }^{2} \cdot \text { 中山哲嚴 }}^{3} \cdot$ 三上信雄 ${ }^{4} \cdot$ 大村智宏 $^{5}$ \\ 佐野朝昭 ${ }^{6}$. 奥野正洋 ${ }^{7} \cdot$ 五十嵐雄介 $^{8}$ \\ Hiroshi YAGI, Koichi SUGIMATSU, Akiyoshi NAKAYAMA, Nobuhiro MIKAMI \\ Tomohiro OHMURA, Akihiro SANO, Masahiro OKUNO and Yusuke IGARASHI
}

\begin{abstract}
In order to investigate the damage mechanism on fishery port facilities at Taro fishery port, field surveys were conducted and stabilities of the facility bodies was examined using the tsunami simulation modeled with flooding. The east and south breakwaters were found to be collapsed inward of the port, wave-dissipating blocks were found scattered in all directions and the breakwater substructions were also destroyed. The modeled results were verified with the flood areas as well as with the height of the watermarks. The results revealed that the height of the watermarks could not be reproduced without the facility collapses in the model. The stability analysis of structures was consistent with the survey results well, in which the east, south and west breakwaters collapsed while the offshore breakwater was intact.
\end{abstract}

\section{1. はじめに}

平成 23 年 3 月 11 日に三陸沖を震源とするマグニチュー ド 9.0 の地震によって発生した大津波は, 地震とともに 東北・関東地方の漁港・漁場 - 漁村に甚大な被害を生じ させた．今回の津波では，多くの漁港施設において従来 の設計条件を遙かに超える外力が作用しており，被災実 態の把握とメカニズムの解明，さらにはそれらを踏まえ た耐津波・耐地震特性を高める技術や設計手法などを早 急に検討することが求められている.

そこで本研究は，今次津波により大きな被災を受けた 岩手県田老漁港を対象として，漁港施設の被災実態及び 被災メカニズムの解明を試みた。田老漁港では，東南の 防波堤，漁港南側の係船岸，防潮堤，陸閘，港内道路· 橋梁, 荷別き所, 水産加工場などの多数の施設が壊滅的 な被害を受けているが，ここでは，代表的な漁港施設に

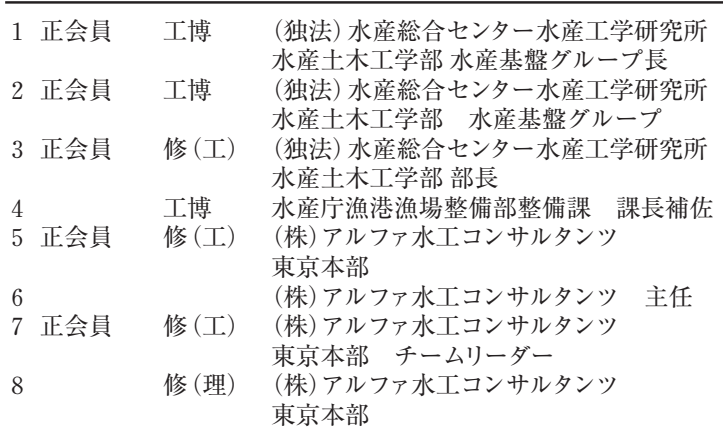

絞り，まず現地調査によって被災実態を把握した上で， 津波遡上シミュレーションによって津波来襲時の状況を 再現し, 推定された被災箇所の外力条件に基づく安定性 照査から被災メカニズムを検討した。

\section{2. 現地調査の概要と被災状況}

本研究では，田老漁港における漁港施設の被災状況を 把握するため，代表的な被災施設を選定し（表-1），漁港 施設の被災部位，被災状況，被災延長等に関する現地調 査・計測を行った。図-1に，調査施設位置を示す。海中 における堤体の飛散状況や洗掘状況などは, 三次元的な

表-1 代表的被災施設一覧

\begin{tabular}{|c|c|}
\hline 施設名 & 諸元等 \\
\hline \multicolumn{2}{|l|}{ 外郭施設 } \\
\hline 東防波堤 & $\begin{array}{l}\text { 重力式混成堤（消波工付きケーソン式） } \\
\text { 天端高：D.L.+4.5m（非一様断面） }\end{array}$ \\
\hline 南防波堤 & $\begin{array}{l}\text { 重力式混成堤（消波工付きケーソン式） } \\
\text { 天端高：D.L.+5.0m }\end{array}$ \\
\hline \multicolumn{2}{|l|}{ 係留施設 } \\
\hline$-4.0 \mathrm{~m}$ 岸壁 & $\begin{array}{l}\text { 重力式係船岸（直立消波ブロック式） } \\
\text { 天端高：D.L.+2.3m }\end{array}$ \\
\hline -4.0m岸壁 & $\begin{array}{l}\text { 重力式係船岸（ブロック積式） } \\
\text { 天端高：D.L.+2.3m }\end{array}$ \\
\hline \multicolumn{2}{|l|}{ 防潮堤 } \\
\hline 防潮堤 & $\begin{array}{l}\text { 堤防（小段あり） } \\
\text { [第1堤東側防潮堤] } \\
\text { 表法勾配 } 1: 1.0 \sim 1: 2.0 \\
\text { 裏法勾配 } 1: 1.0 \sim 1: 2.0 \\
\text { 天端高：D.L.+10.7m }\end{array}$ \\
\hline
\end{tabular}




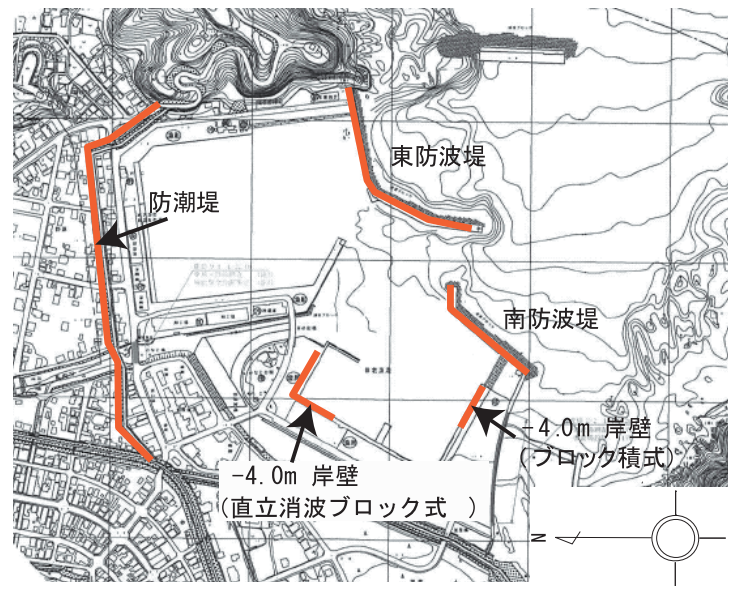

図-1 調查施設位置

地形を計測出来るスワス測深器（C3D）による水中調査 結果と被災前後の航空写真から整理した. 本研究では紙 面の都合上, 外郭施設として南防波堤, 係留施設として$4.0 \mathrm{~m}$ 岸壁についての検討結果を報告する.

\section{(1) 南防波堤}

図-2に見られる通り，南防波堤について，防波堤基部 の1スパンは上部工のみ流出し, 防波堤先端の 2 スパン は顕著な損傷は見受けられなかったが，それ以外のケー ソン（約10函）が堤内側に移動・飛散していた。最大移 動距離は $150 \mathrm{~m}$ 程度であり, 堤幹部中央付近の移動距離 が特に大きい傾向があった. 水中調査によると堤内側で 地盤高の低下が発生しており, 津波による洗掘が推定さ れる. なお，東防波堤に対する同様の調査からはマウン ドの天端高が全体的に大きく低下している箇所はなく, マウンドの洗掘・流出状況が, 東側と南側の防波堤で異 なっていた。

施設の被災要因としては，港内側にケーソンが飛散し ている状態や, 後述する津波シミュレーション結果など から, 津波高が最大で, 第2 波の押し波によって防波堤 が倒壊したと推測される.

\section{(2) $-4.0 \mathrm{~m}$ 岸壁}

図-3に示す田老漁港新港側（南側）にある直立消波式 の-4.0m岸壁では, 広い範囲で被姼が確認された。この うち北側隅角部については, 角部を除き全区間が被災し, 西側岸壁は直立消波ブロック3段積のうち最上段が, 東 側岸壁は最上段と2段目が全て流出していた．流出した ブロックは背後の漁港用地, 田代川に飛散しており（海 側への飛散なし), 直立消波ブロックが流出した岸壁背 後は, エプロン, 裏込土, アスファルト舗装が流出し大 きく決壊していた，直立消波ブロック式の岸壁は，その 構造上内部に海水が浸入する形となっており, 強い流れ が流入すれば揚圧力でブロックが浮上しやすく，それに より流出・飛散したものと推測される. なお, 被災の程

\section{(a) 水中調査結果}

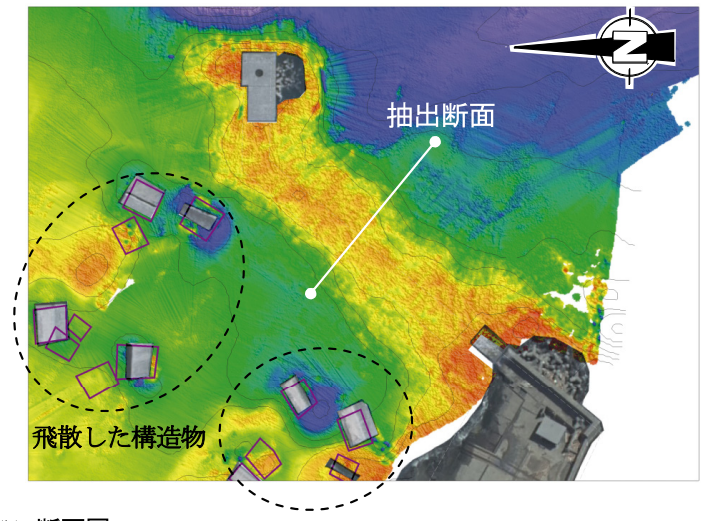

(b) 断面図

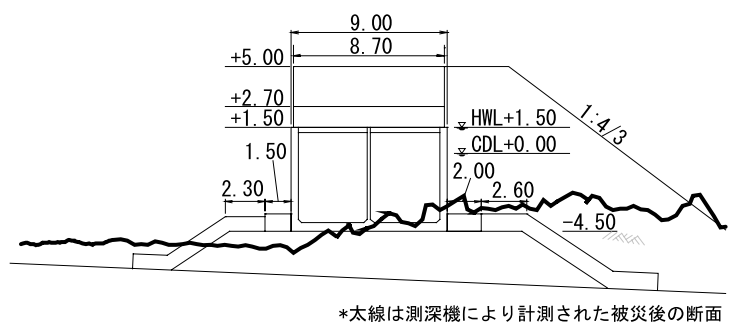

図-2 被災調查結果（南防波堤）

(a) 水中調査結果, (b) 断面図

(a) 水中調査結果

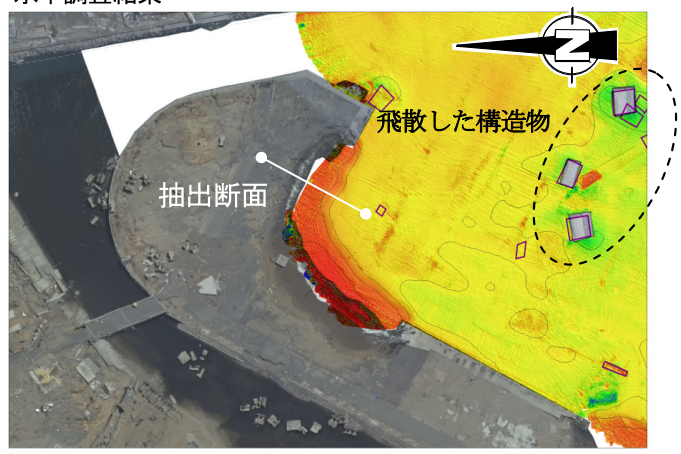

(b) 断面図

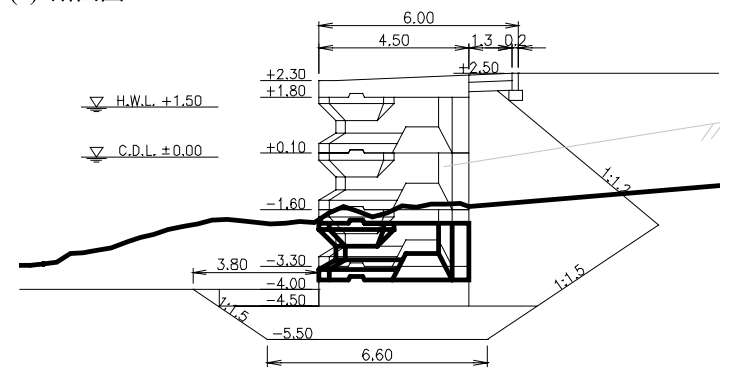

*太線は測深機により計測された被災後の断面

図-3 被災調查結果 (-4.0m岸壁)

(a) 水中調査結果, （b）断面図 


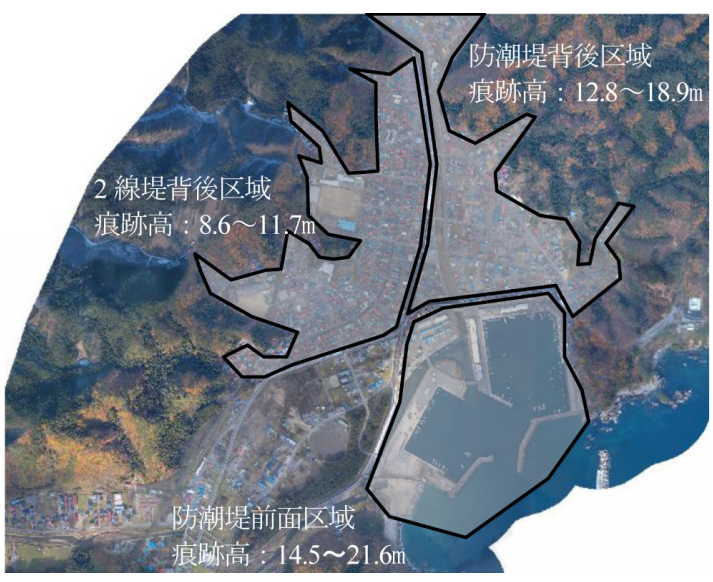

図-4＼cjkstart痕跡高の分布特性（田老漁港周辺）

度は，狭い港内でも場所ごとに差異が見られ（南側隅角 部の岸壁では被災が小)，これは流出の主因と考えられ る流速の大きさや流向を反映したものと推察された.

\section{3. 痕跡高の分布特性}

東北地方太平洋沖地震津波合同調査グループによって 公表されている痕跡高（http://www.coastal.jp/ttjt/, 2012/3/1更新）を用いて，田老漁港周辺に㧍ける痕跡高 の分布特性を把握した，痕跡高の分布特性より，図-4に 示すように防潮堤前面区域，破堤した防潮堤背後区域及 び2線堤背後区域の3つの区域に分けることができる. 区域による痕跡高の違いには，防波堤や防潮堤などの漁 港施設の被災が影響していると推察される。これについ ては, 次章の被災メカニズム検討の際に検証を行う.

\section{4. 津波遡上シミュレーションに基づく被災メカ ニズムの推定}

次に，対象施設の被災メカニズムを把握するために， 津波来襲時の外力を推定するための数值計算を実施し,

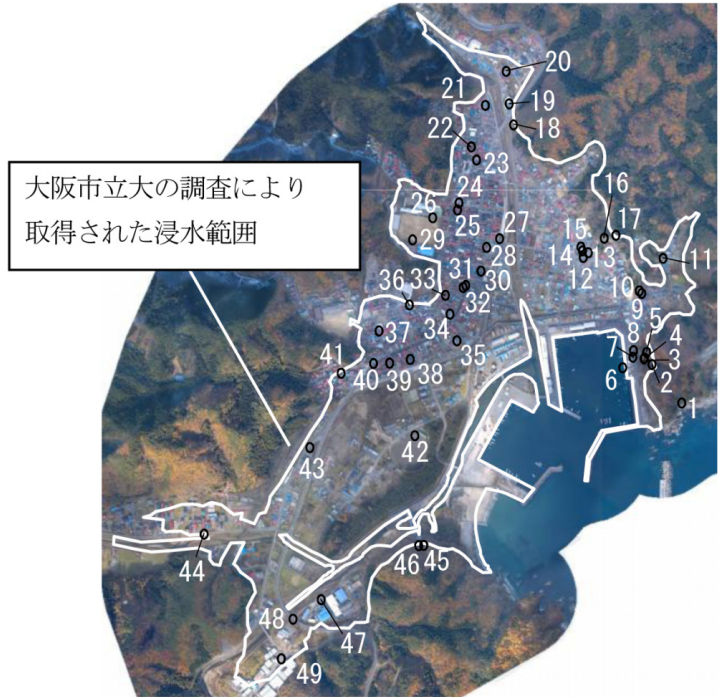

図-5 痕跡高抽出地点

それに基づく安定性照査から被災メカニズムの推定を行 った。

（1）津波遡上シミュレーション

数值計算の支配方程式は，非線形長波モデルを採用し

表-2 計算条件一覧

\begin{tabular}{|c|c|}
\hline 項 目 & 内容 \\
\hline 解析領域 & $\begin{array}{l}\text { 対象漁港と対象波源を含む東日本範囲 } \\
\text { 1350m格子から5m格子までネスティング }\end{array}$ \\
\hline 波源モデル & 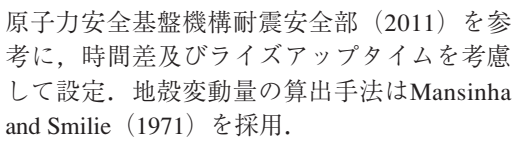 \\
\hline 潮位条件 & $\begin{array}{l}\text { 宮古（海上保安庁）での推算潮位を参考にし } \\
\text { てT.P.-0.57 m (2011/3/11 15:00）として設定 }\end{array}$ \\
\hline 計算時間 & $\begin{array}{l}\text { 津波の最大波を十分含む時間帯として地震発 } \\
\text { 生後3時間, 時間解像度 : } 0.1 \mathrm{sec}\end{array}$ \\
\hline その他 & $\begin{array}{l}\text { 粗度係数は, 土地利用に応じて設定 } \\
\text { 構造物は, 被災前の天端高を採用 (T.P.基準) } \\
\text { 海底地盤の鉛直变位量を天端高に反映 }\end{array}$ \\
\hline
\end{tabular}

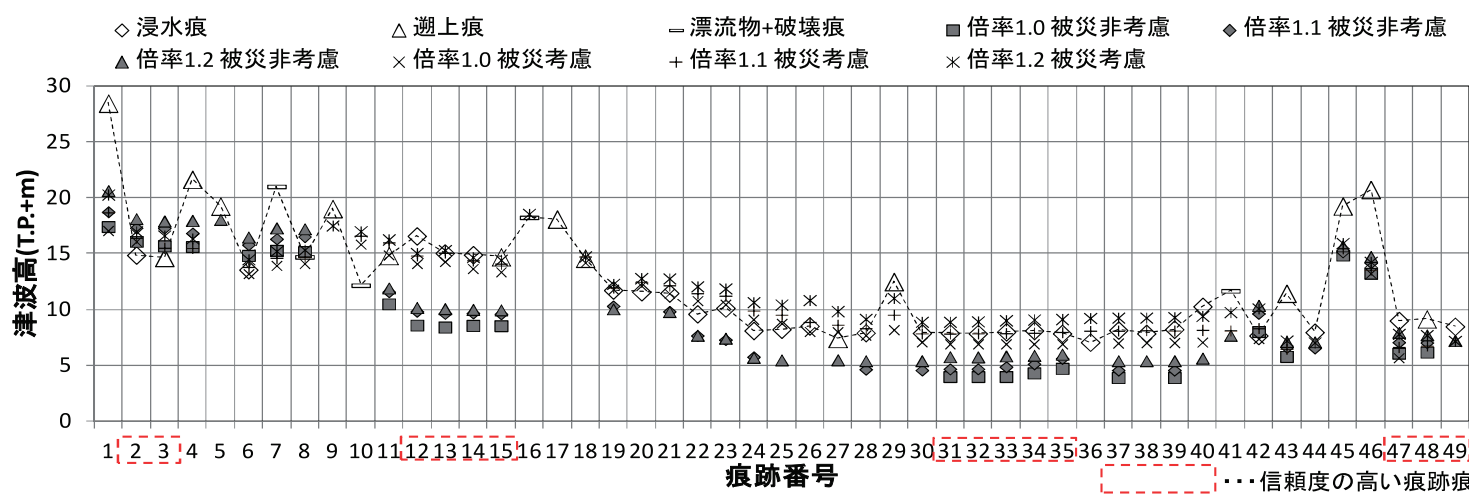

図-6 津波シミュレーション結果と現地調査による津波痕跡高の比較 
た。代表的な計算条件を表-2に示す，計算結果の再現性 を確認するために，図-5に示す東北地方太平洋沖地震津 波合同調查グループ (http://www.coastal.jp/ttjt/, 2012/3/1 公表）により取得された津波痕跡の痕跡高と, 大阪市立 大の現地踏査によって取得された津波の浸水範囲を計算 結果と比較した.

断層モデルのすべり量は, 1.0 倍から 1.2 倍まで, 構造 物の被災非被災条件を合わせてキャリブレーションを行 った，痕跡高と計算水位の比較は, 図-6に示す通りであ る. その結果, すべり量を 1.1 倍とすることで, 調查結 果を一定精度で再現することが確認される。

\section{(2) 被災メカニズムの検討}

ここでは，津波遡上シミュレーション結果から，施設 周辺の流速及び水位，また八木ら（2012）に扔いて示し

ている津波に対する防波堤安定照査手法を用いて被災 メカニズムの検討を行った.

\section{a) 南防波堤}

図-7に，防波堤前後の代表点において計算結果より抽 出した水位及び流速に加え, 安定性照查手法から算出さ れた安全率の経時変化を示す。これを見ると, 押し波時 に港内外で最大 $6 \mathrm{~m}$ 程度の水位差が生じており, 堤体前 面では $4 \mathrm{~m} / \mathrm{s}$ 程度の最大流速が生じている．この時に安全 率が1.0を下まわっており，この事は，押し波の水位差 による港内向きの力と, 港内向きの動圧が同時に作用し, 堤体の飛散に至ったことを示している.

\section{b) $-4.0 \mathrm{~m}$ 岸壁}

現地調査結果から, 直立消波式岸壁の被災には津波に より作用した流速が重要であることが推察されため, 数 值計算結果から対象施設周辺の流速場を調べた. 図-8に,

\section{(a) 南防波堤}
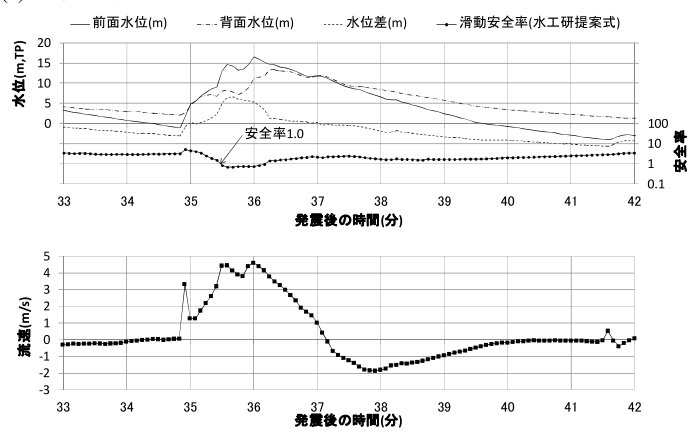

(b) 東防波堤

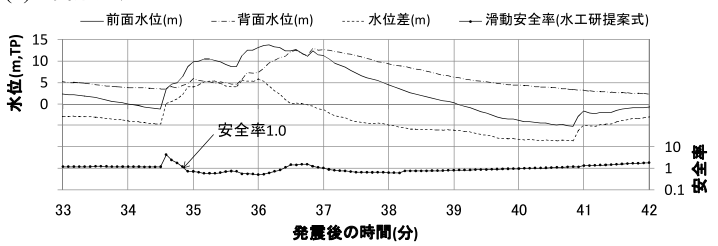

図-7 防波堤前後の代表点における各種パラメータの 経時変化

（a）南防波堤，（b）東防波堤

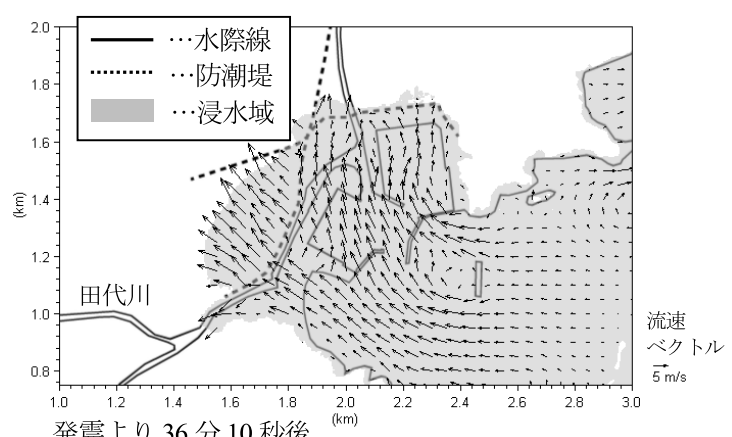

発震より 36 分 10 秒後

図-8 田老漁港周辺の2波目押し波時における代表的な流速分布

田老漁港周辺の代表的な流速分布（津波 2 波目押し波時） を示す。これを見ると，被災のなかった直立消波式岸壁 部分では, 岸壁背後の田代川側から津波が流入する流速 （直立消波ブロック正面に向かう流速ではない）となっ て抢り,一方, 被災した箇所については陸向きの流速 (ブロック正面に向かう流速. 北側の直立消波岸壁前面 で最大は $5 \sim 6 \mathrm{~m} / \mathrm{s}$ ) が生じていた。このような流況の違 いにより直立消波ブロックに対する揚力の作用が変化 し，被災状況に違いが生じたと推察される。

\section{（3）被災メカニズムを導入した数值解析}

上記のように各施設の被災メカニズムが推定されたの で，ここではその結果を反映させて，防波堤の非定常な 破堤プロセスを導入した津波遡上シミュレーションを試 みた。防波堤破堤モデルには, 先述の被災メカニズムで 参照したのと同じ，八木ら（2012）において提案されて いる越流時の防波堤に作用する波圧式を用いて，防波堤 の滑動及び転倒の安定性照査を時々刻々行い, 安全率が 1を切った瞬間に構造物デー夕を除去するモデルを採用 し計算を実施した。な书，防潮堤の被災については，破 堤した箇所の夕越流と同時に破堤する条件を設定してい る。その結果を図-9に示す。破堤メカニズムを考慮した 場合, 防波堤等による津波の遮蔽効果が, 破堤メカニズ 厶を考慮しない場合と比較して小さくなるため, 漁港の 岸壁及び背後の防潮堤前面に打ける水位の上昇量が破堤 メカニズムを考慮しない場合と比較して大きくなること が確認された。また，防潮堤の倒壊を考慮すると，表-3 に示す通り浸水範囲の再現性が向上することも確認さ れた。

表-3 計算ケースによる浸水範囲の比較

\begin{tabular}{|c|c|c|c|}
\hline 計算ケース & $\begin{array}{l}\text { 浸水面積 } \\
\text { (実測：ha) }\end{array}$ & $\begin{array}{l}\text { 浸水面積 } \\
\text { (計算 : ha) }\end{array}$ & $\begin{array}{l}\text { 浸水面積比 } \\
\text { =計算 /実例 }\end{array}$ \\
\hline $\begin{array}{c}\text { 破堤メカニズム } \\
\text { 非考慮 }\end{array}$ & \multirow{2}{*}{ 114.04ha } & 99.84ha & 0.88 \\
\hline $\begin{array}{c}\text { 破堤メカニズム } \\
\text { 考慮 }\end{array}$ & & 115.37ha & 1.01 \\
\hline
\end{tabular}


表-4 安定性昭查結果

\begin{tabular}{c|c|c|c|c}
\hline 対象施設 & 破堤時間 & $\begin{array}{c}\text { 滑動 } \\
\text { 安全率 }\end{array}$ & $\begin{array}{c}\text { 前面水位 } \\
(\mathrm{m})\end{array}$ & $\begin{array}{c}\text { 水位差 } \\
(\mathrm{m})\end{array}$ \\
\hline 沖防波堤 & 非被災 & 1.07 & 15.49 & 9.77 \\
\hline $\begin{array}{c}\text { 東防波堤 } \\
\text { 堤頭部 }\end{array}$ & 34分50秒 & 0.91 & 10.50 & 6.00 \\
\hline $\begin{array}{c}\text { 東防波堤 } \\
\text { 基部 }\end{array}$ & 34分55秒 & 0.72 & 8.69 & 4.05 \\
\hline $\begin{array}{c}\text { 南防波堤 } \\
\text { 堤幹部 }\end{array}$ & 35分30秒 & 0.78 & 14.04 & 5.27 \\
\hline 西防波堤 & 35分50秒 & 0.88 & 10.15 & 3.28 \\
\hline
\end{tabular}

(a) 破堤メカニズム非考慮時

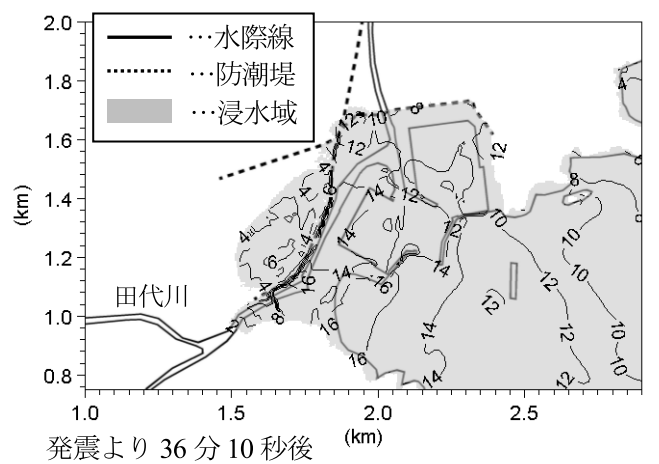

(b) 破堤メカニズム考慮時

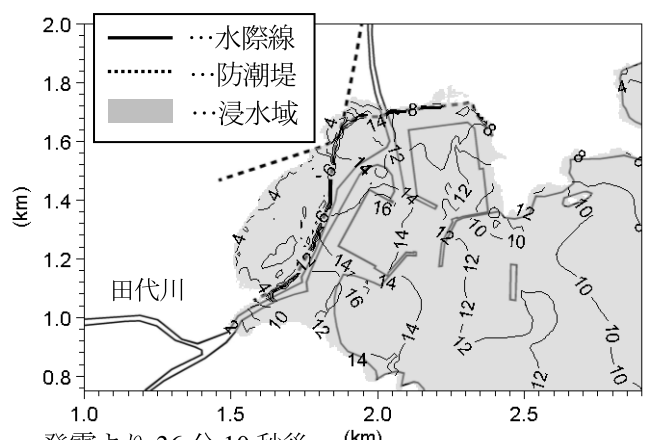

発震より 36 分 10 秒後 $(\mathrm{km})$

図-9 田老漁港周辺の2波目押し波時における代表的な 水位分布 $(\mathrm{m}, \mathrm{TP}$ 基準

（a）破堤メカニズム未考慮時，（b）破堤メカニズム考慮時

表-3に，浸水範囲を比較した結果を示す。表-3より， 浸水面積比（計算/実績）は破堤メカニズムを考慮した場 合に再現性が向上することが分かった。また，表-4に，
安定性照査結果を示すが，沖防波堤は破堤には至らず， 東防波堤，南防波堤，西防波堤の破堤条件を満たすなど 実際の被災課程に対応していることが確認された。

以上の結果から，破堤メカニズムを考慮した数值解析 シミュレーションは，今次津波の被災の状況をより精度 良く再現することができたと考えられる.

\section{5. 結論}

本研究において得られた結論を以下に取りまとめる.

（1）現地調査より田老漁港の漁港施設の被災状況を把握 した. 本研究で主な検討対象とした南防波堤は港内側 に堤体が倒壊し, 最大で $150 \mathrm{~m}$ 程度ケーソンが飛散し ており，マウンドも原形をとどめてはいなかった。一 方，岸壁については，直立消波式岸壁部分での被災が 大きく，検討対象とした南側泊地では，漁港背後に最 大約 $100 \mathrm{~m}$ 程度飛散していた。

（2）津波遡上シミュレーションとそれに基づく安定性照 查解析から，南防波堤については，第 2 波の押し波の 水平力で被災することが確認された。また，直立消波 式岸壁については，被災の大きい箇所でブロック正面 に向かう流速が大きく，ブロック内部に強い流れが流 入し被災したことが数值シミュレーション結果からも 裏付けられた。

（3）津波遡上シミュレーションに非定常な防波堤の被災 プロセスを導入することで，漁港周辺での津波の挙動 や被災状況をより精度良く再現することが可能である ことを示した.

謝辞 : 本研究は, 平成 23 年漁港施設等設計条件見直し調 査（水産庁）による成果である。ここに感謝の意を表す。

\section{参 考 文 献}

原子力安全基盤機構 耐震安全部（2011）：原子力事業者が実 施した平成 23 年東北太平洋沖地震により発生した津波の再 現計算結果等に係るクロスチェック解析, 地震・津波3-4. 科学技術振興機構：科学技術情報流通技術基準ハンドブック 2003 年版（オンライン）, http://www.jst.go.jp/SIST/ hand book/sist02sup/, 参照2005-04-25.

八木 宏・杉松宏一・中山哲嚴・ 三上信雄 - 大村智宏 - 佐野朝 昭・奥野正洋・五十嵐雄介 (2012) : 東北地方太平洋沖地 震津波による漁港施設（防波堤）の被災状況とその原因に ついて, 土木学会論文集 B2 (海岸工学), Vol.68, No.1, 印刷中. 